\title{
Prevalence and Evaluation of Different Germplasm Lines/Cultivars against Anthracnose of Bottle Gourd under Artificial Inoculation Conditions
}

\author{
Ankit Kumar, Narender Singh*, Kushal Raj, Annie Khanna and Harbinder Singh
}

Department of Plant Pathology, CCS Haryana Agricultural University, Hisar, Haryana, India

*Corresponding author

\begin{tabular}{|c|}
\hline Keywords \\
\hline $\begin{array}{l}\text { Bottle gourd, } \\
\text { Colletotrichum } \\
\text { lagenarium, Disease } \\
\text { severity, Germplasms }\end{array}$ \\
\hline Article Info \\
\hline $\begin{array}{l}\text { Accepted: } \\
\text { 04 February } 2018 \\
\text { Available Online: } \\
10 \text { March } 2018\end{array}$ \\
\hline
\end{tabular}

A B S T R A C T

Bottlegourd is prone to various fungal, bacterial and viral diseases. Among various fungal diseases, anthracnose, downy mildew and cercospora leaf spot are prevalent in different bottlegourd growing areas. Anthracnose caused by Colletotrichum lagenarium (Pass) Ellis. and Halsted is of major economic importance. The pathogen is seed borne in nature but initiation as well as spread of disease largely depends upon the environmental factors. This disease is widespread under both greenhouse and field cultivation resulting in poor fruit quality and yield. Keeping its economic importance, the experiment was under taken to study the survey among major growing areas and screening of different genotypes under field conditions. During survey minimum per cent disease intensity on leaves was observed in Arjaheri village of Karnal district, whereas on fruits per cent disease intensity was minimum in Dadupur village of Karnal district in Haryana. A total of 24 cultivars/germplasm lines were screened under artificial inoculation conditions created at Plant Pathology farm of CCS HAU, Hisar (Haryana). All the bottlegourd germplasms were sown on $30^{\text {th }}$ June 2016. Two plants per cultivars/germplasm line were maintained and inoculated with a standard spore suspension $\left(3 \times 10^{4}\right.$ conidia ml $\left.{ }^{-1}\right)$ at 4-5 leaf stage. Per cent disease intensity was recorded 15 days after inoculation. The entries/germplasms/cultivars and categorized as per the status of disease intensity. Three genotype viz., K-92420, GH-3 and GH-11 were found resistant to anthracnose of bottlegourd whereas, genotypes K92426 and Gh-18 were moderately resistant to anthracnose and remaining genotypes were susceptible to the disease.

\section{Introduction}

Bottle gourd is a very important crop in India and belongs to cucurbitaceae family. It can be grown both during warm and rainy season in northern parts of India. It has wide genetic diversity and is grown throughout the tropics and subtropics of the world. The origin of bottle gourd is assumed from Africa and domestication occurred in tropical low lands of south Central America. In India bottle gourd is cultivated in an area of 103.23 thousand ha with productivity of $17.61 \mathrm{ton} / \mathrm{ha}$ (Anonymous, 2016). In Haryana bottle gourd is cultivated during summer and rainy season. Bottle gourd is attacked by various fungal, bacterial and viral diseases. Among fungal diseases anthracnose of bottle gourd caused by Colletotrichum lagenarium is an important disease resulting in considerable damage to 
the crop. In India the disease was first reported by Mundkur on kakri (Cucumis melo var. utilissimus Roxb.) and kaddu (Lagenaria siceraria (Monila) Standl.) in 1937. In Haryana the disease was first observed by Madan and Grover in 1977. Colletotrichum lagenarium is an asexually reproducing organism and produces conidia in acervuli with rare presence of setae (Mundkur, 1937). Several species of plant pathogenic fungi under the genus Colletotrichum cause anthracnose in bottle gourd, other vegetables and fruits.

Anthracnose of bottle gourd regularly occurs in different bottle gourd growing area during both the seasons. The pathogen is seed borne in nature but initiation as well as spread of disease largely depends upon the environmental factors. This disease is widespread under both greenhouse and field cultivation resulting in poor fruit quality and yield. Direct infection on the fruit also results in loss of market value.

The symptoms appears as brownish specks, which grows into angular and roughly circular spots on the leaves, whereas on young fruits numerous water soaked, depressed, oval or circular spots are observed. Colletotrichum lagenarium also cause premature plant death by reducing the photosynthetic surface area to the extent of 29-42 per cent, resulting in yield losses of 6-48 per cent.

The disease is reported to occur in epiphytotic form in India (Madan and Grover, 1977) and Japan (Kobayshi et. al., 1998). The extent of damage inflicted by the disease has necessitated conducting studies on some important aspects of the disease. Keeping in view the importance of this disease in this region, the present study has been under taken with the objectives to study prevalence/status and screening of different genotypes against anthracnose disease of bottle gourd.

\section{Materials and Methods}

Survey of anthracnose disease in major bottle gourd growing locations of Haryana

Survey of bottle gourd anthracnose was conducted during month of July-August, 2016 in different bottle gourd growing locations of five districts viz., Kurukshetra, Karnal, Kaithal, Ambala and Yamuna nagar of Haryana. Two villages from each district were selected.

Twenty five vines per field were tagged randomly. Observations on per cent anthracnose intensity on leaves and fruits were recorded during first and second survey, respectively by using the following scale as given by Chauhan, (2002) on the basis of symptoms as in (Figure 1).

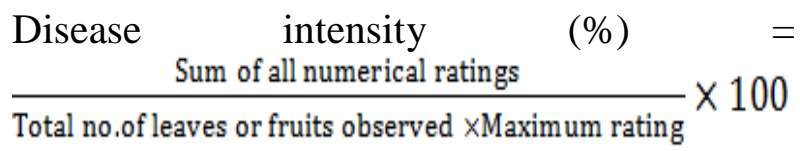

Screening of different germplasm lines /cultivars against anthracnose of bottle gourd under artificial inoculation conditions

A total of 24 cultivars/germplasm lines were screened under artificial inoculation conditions at Plant Pathology farm of CCS HAU, Hisar during kharif, 2016.

Bottle gourd germplasms were sown on $30^{\text {th }}$ June 2016. Two plants per cultivars/germplasm line were maintained and inoculated with a spore suspension $\left(3 \times 10^{4}\right.$ conidia $\mathrm{ml}^{-1}$ ) at 4-5 leaf stage. Disease intensity (\%) was recorded 15 days after inoculation.

The entries/ Germplasm/cultivars are categorized as per the status of disease intensity 
Fig.1 Symptomatology of Colletotrichum lagenarium causing bottle gourd anthracnose
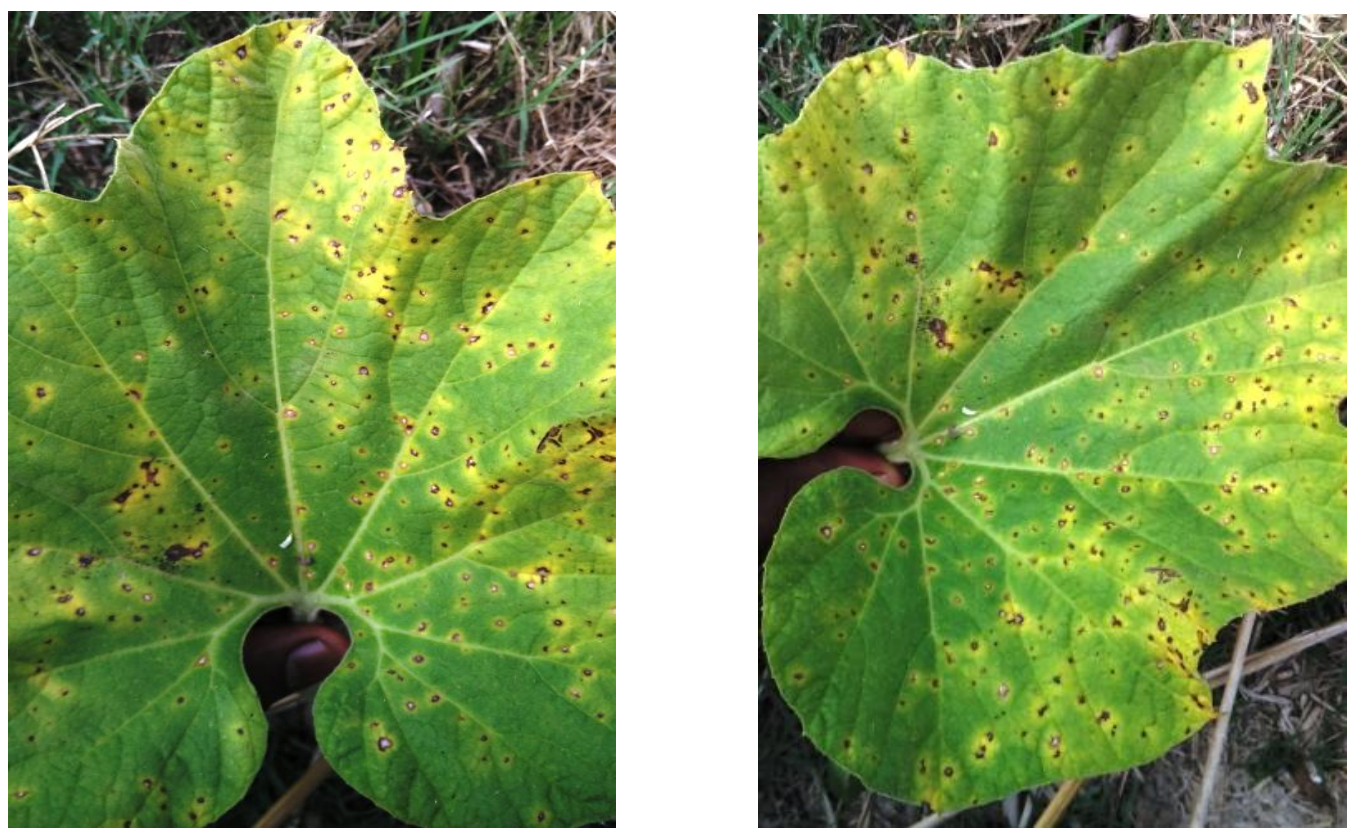

(On leaves)

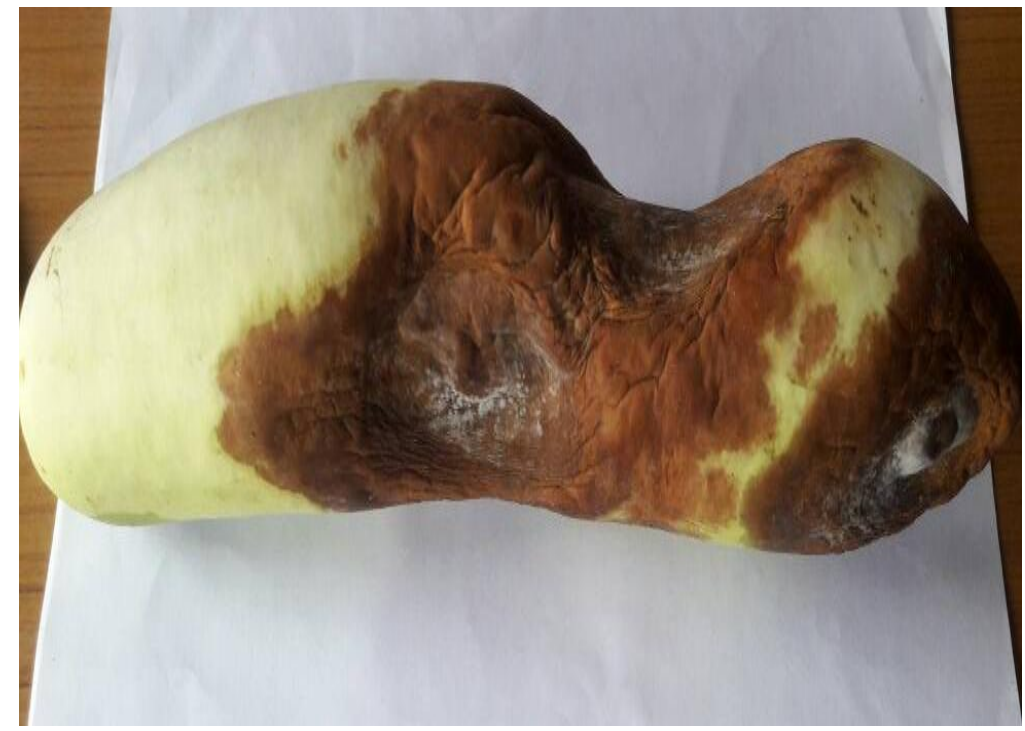

(On fruits)

Survey of anthracnose disease in major bottle gourd growing locations of Haryana

\begin{tabular}{|c|c|}
\hline Grade & Description \\
\hline $\mathbf{0}$ & No spots/leaf or fruit \\
\hline $\mathbf{1}$ & $1-10$ spots/leaf or fruit \\
\hline $\mathbf{2}$ & $11-20$ spots/leaf or fruit \\
\hline $\mathbf{3}$ & $21-50$ spots/leaf or fruit \\
\hline $\mathbf{4}$ & More than 50 spots/leaf or fruits \\
\hline
\end{tabular}


Table.1 Prevalence of bottle gourd anthracnose in major bottle gourd growing location(s) of Haryana

\begin{tabular}{|c|c|c|c|}
\hline Districts & Villages & $\begin{array}{c}\text { Disease intensity (\%) } \\
\text { on leaves }\end{array}$ & $\begin{array}{c}\text { Disease intensity }(\%) \\
\text { on fruits }\end{array}$ \\
\hline \multirow{2}{*}{ Kurukshetra } & Amin & 59.25 & 67.50 \\
\hline \multirow{2}{*}{ Kaithal } & Dayalpur & 61.75 & 71.50 \\
\hline \multirow{2}{*}{ Karnal } & Pabnawa & 67.75 & 71.00 \\
\hline & Khanoda & 63.50 & 69.00 \\
\hline \multirow{2}{*}{ Ambala } & Dadupur & 56.75 & 61.50 \\
\hline & Arjaheri & 52.75 & 68.50 \\
\hline Yamuna nagar & Barara & 75.75 & 80.50 \\
\hline & Hema Majra & 69.25 & 74.50 \\
\hline & Bhut Majra & 62.75 & 72.50 \\
\hline & Akal Garh & 70.25 & 75.00 \\
\hline
\end{tabular}

Table.2 Screening of bottle gourd genotypes against anthracnose under disease stress conditions

\begin{tabular}{|l|}
\hline Category \\
\hline Resistant(R) \\
\hline Moderately resistant(MR) \\
\hline Moderately susceptible(MS) \\
\hline Susceptible(S) \\
\hline Highly Susceptible(HS) \\
\hline
\end{tabular}

\section{Category Disease intensity $(\%)$}

Highly Resistant (HR):

Resistant (R):

Moderately susceptible (MS):

Susceptible (S):

Highly susceptible (HS):

\section{Results and Discussion}

\section{Survey of bottle gourd anthracnose}

It is evident from the observations that per cent disease intensity on fruits was higher than per cent disease intensity on leaves at each surveyed locations/districts (Table 1).

Anthracnose of bottle gourd was recorded maximum on leaves $(75.75 \%)$ and fruits $(80.50 \%)$ in Barara village of Ambala district followed by Akal garh, location with anthracnose on leaves $(70.25 \%)$ and on fruits

\section{Bottle gourd entries/genotypes}

K-92420, GH-3, GH-11
K-92462, GH-18
K-92372, K-92414, K-92436, GH-19
K-42345, K-92363, K-92404, K-92424, GH-10, GH-14, GH-25,
GH-28, GH-23
PSPL, K-92371, K-92426, K-92428, K-92465, GH-29

(75.00\%) and minimum per cent disease intensity on leaves $(52.75 \%)$ was observed in Arjaheri village of Karnal district, whereas on fruits per cent disease intensity $(61.50 \%)$ was minimum in Dadupur village of Karnal district in Haryana.

Screening of bottle gourd genotypes against bottle gourd anthracnose

The experiment was conducted under field conditions during kharif 2016. Twenty four bottle gourd genotypes were screened against anthracnose disease under artificial disease stress conditions. The observations were presented in Table 2.

It is evident from results that three genotypes viz., K-92420, GH-3 and GH-11 were resistant to anthracnose of bottle gourd whereas, genotypes K-92426 and GH-18 were moderately resistant to bottle gourd anthracnose 
and remaining genotypes were susceptible to the disease.

During survey (kharif 2016), it was observed that the prevalence of bottle gourd anthracnose ranged from 52.75-75.75 per cent and 61.5080.50 per cent on leaves and fruits, respectively. Anthracnose intensity was observed maximum in Ambala district, whereas it was minimum in Karnal district. Our observations are corroborative to Chauhan (2002) who reported that per cent disease intensity on fruits was generally higher as compared to that on leaves in different locations of Haryana. Similarly, Gupta et al., (2009) observed that bottle gourd crop was severely affected with anthracnose disease during 2008 in Himachal Pradesh. The variation in anthracnose intensity might be attributed due to variation in environmental conditions, inoculum potential of isolates, inoculum density as well as host variety.

Out of 24 bottle gourd germplasm lines, three germplasms lines viz., K-92420, GH-3 and GH11 were found resistant to the anthracnose disease. Chauhan and Bhatia (2013) found that germplasm GH-3, GH-9 and winter ghiya-1 were resistant to bottle gourd anthracnose under disease stress conditions. It is concluded that lines K-92420, GH-3 and GH-11 which were resistant under artificial disease stress conditions may be utilized in donors in resistance breeding programme.

In conclusion, Survey conducted during Kharif 2016, minimum per cent disease intensity on leaves was observed in Arjaheri village of Karnal district, whereas on fruits per cent disease intensity was minimum in Dadupur village of same district Three genotypes K-
92420, GH-3 and GH-11 were found resistant, whereas, only two genotypes K-92462 and GH18 were found moderately resistant to the anthracnose disease under artificial inoculation conditions. The resistant source identified can be used for future breeding programme.

\section{References}

Anonymous, (2016). www.Indiastat.com.

Chauhan, R.S. (2002). Studies on anthracnose disease of bottle gourd caused by Colletotrichum lagenarium (Pass.) Ell. and Halsted. Thesis, Department of plant pathology, C.C.S., Haryana Agricultural University, Hisar, India, 47 pp.

Chauhan, R.S., and Bhatia, J.N., (2013). Screening of bottle gourd genotypes against anthracnose disease under natural as well as artificial epiphytotic conditions. Plant Disease Research 28(1): 92-93.

Gupta, S.K., Jarial, K. and Rana, S. (2009). Occurance of bottle gourd anthracnose in Himachal Pradesh. Journal of Plant disease Sciences 4(2): 225-226.

Kobayashi, Y., Kimishima, E. and Tokei, R. (1998). Anthracnose of pumpkin caused by Colletotrichum orbiculare (Berk. And Mnt.) Arx intercepted in important plant quarantine in Japan. Research Bulletin of the Plant Protection Service, Japan 34: 55-58.

Madan, R.L. and Grover, R.K. (1977). Some pathological studies on anthracnose affecting bottlegourd. Indian Phytopathology 30: 392-398.

Mundkur, B.B. (1937). Anthracnose of cucurbits in Punjab. Current Science 12: 647.

\section{How to cite this article:}

Ankit Kumar, Narender Singh, Kushal Raj, Annie Khanna and Harbinder Singh. 2018. Prevalence and Evaluation of Different Germplasm Lines/Cultivars against Anthracnose of Bottle Gourd under Artificial Inoculation Conditions. Int.J.Curr.Microbiol.App.Sci. 7(03): 393-397. doi: https://doi.org/10.20546/ijcmas.2018.703.045 